\title{
Pulmonary Pathologic Findings of Fatal 2009 Pandemic Influenza A/H1N1 Viral Infections
}

\author{
James R. Gill, MD; Zong-Mei Sheng, MD, PhD; Susan F. Ely, MD, MPHTM; Donald G. Guinee Jr, MD; Mary B. Beasley, MD; James \\ Suh, MD; Charuhas Deshpande, MD; Daniel J. Mollura, MD; David M. Morens, MD; Mike Bray, MD; William D. Travis, MD; \\ Jeffery K. Taubenberger, MD, PhD
}

- Context.-In March 2009, a novel swine-origin influenza A/H1N1 virus was identified. After global spread, the World Health Organization in June declared the first influenza pandemic in 41 years.

Objective.-To describe the clinicopathologic characteristics of 34 people who died following confirmed A/ H1N1 infection with emphasis on the pulmonary pathology findings.

Design.-We reviewed medical records, autopsy reports, microbiologic studies, and microscopic slides of 34 people who died between May 15 and July 9, 2009, and were investigated either by the New York City Office of Chief Medical Examiner (32 deaths) or through the consultation service of a coauthor ( 2 deaths).

Results.-Most of the 34 decedents $(62 \%)$ were between 25 and 49 years old (median, 41.5 years). Tracheitis, bronchiolitis, and diffuse alveolar damage were noted in most cases. Influenza viral antigen was

nfluenza A viruses are important causes of respiratory disease in pandemic form and in annual seasonal influenza. At least 36000 people die annually of influenza complications in the United States. ${ }^{1}$ Pandemic influenza emerges sporadically and may differ dramatically in impact. ${ }^{2,3}$ The 1918 pandemic killed approximately 675000 people in the United States and at least 40 million people worldwide., ${ }^{4,5}$ Pandemics in 1957 and 1968 were significantly less severe. ${ }^{2}$

\footnotetext{
Accepted for publication November 4, 2009.
}

From the New York City Office of Chief Medical Examiner and Department of Forensic Medicine, New York University School of Medicine (Drs Gill and Ely); the Laboratory of Infectious Diseases (Drs Sheng and Taubenberger), the Integrated Research Facility (Drs Mollura and Bray), and the Office of the Director (Dr Morens), National Institute of Allergy and Infectious Diseases, National Institutes of Health, Bethesda, Maryland; the Department of Pathology, Virginia Mason Medical Center, Seattle, Washington (Dr Guinee Jr); the Department of Pathology, Mount Sinai Medical Center, New York, New York (Dr Beasley); the Department of Pathology, Stony Brook University Medical Center, Stony Brook, New York (Dr Suh); the Department of Pathology, University of Pennsylvania, Philadelphia (Dr Deshpande); and the Department of Pathology, Memorial Sloan Kettering Cancer Center, New York, New York (Dr Travis).

The authors have no relevant financial interest in the products or companies described in this article.

Reprints: Jeffery K. Taubenberger, MD, PhD, National Institute of Allergy and Infectious Diseases, National Institutes of Health, 33 North Drive, Bethesda, MD 20892-3203 (e-mail: taubenbergerj@niaid.nih.gov). observed most commonly in the epithelium of the tracheobronchial tree but also in alveolar epithelial cells and macrophages. Most cases were reverse transcription-polymerase chain reaction positive for influenza. Histologic and microbiologic autopsy evidence of bacterial pneumonia was detected in $55 \%$ of cases. Underlying medical conditions including cardiorespiratory diseases and immunosuppression were present in $91 \%$ of cases. Obesity (body mass index, $>30$ ) was noted in $72 \%$ of adult and adolescent cases.

Conclusions.-The pulmonary pathologic findings in fatal disease caused by the novel pandemic influenza virus are similar to findings identified in past pandemics. Superimposed bacterial infections of the respiratory tract were common. Preexisting obesity, cardiorespiratory diseases, and other comorbidities also were prominent findings among the decedents.

(Arch Pathol Lab Med. 2010;134:E1-E9)

In March 2009, a novel influenza A virus of H1N1 subtype was identified from patients in Mexico and the United States. The virus was a novel genetic reassortant derived from 2 preexisting swine influenza virus lineages. ${ }^{6}$ During the spring, the outbreak spread throughout the United States and globally. In June, the World Health Organization declared the first influenza pandemic in 41 years. ${ }^{7}$ As of November 8, 2009, the World Health Organization had reported more than 503536 confirmed H1N1 infections and at least 6260 deaths, although the case total is undoubtedly larger ${ }^{8}$ and is rising as the pandemic continues to spread globally.

Whereas in seasonal influenza most deaths occur in persons older than 65 years, ${ }^{9}$ the 2009 pandemic has predominantly affected the young, with a median age between 12 and 22 years. ${ }^{10-12}$ Most infections have been self-limited, but deaths have also occurred in a younger age group than expected for seasonal influenza (median age, 37 years).$^{13}$ In a subset of fatal cases for which medical records were available, $91 \%$ had preexisting underlying medical conditions, notably cardiac and respiratory diseases, immunosuppression, pregnancy, and obesity, the latter being an unexpected finding based on evidence from prior pandemics. ${ }^{13}$

We investigated 34 deaths with confirmed novel A/ H1N1 respiratory infection, reviewing available clinical, radiologic, pathologic, and microbiologic data. 


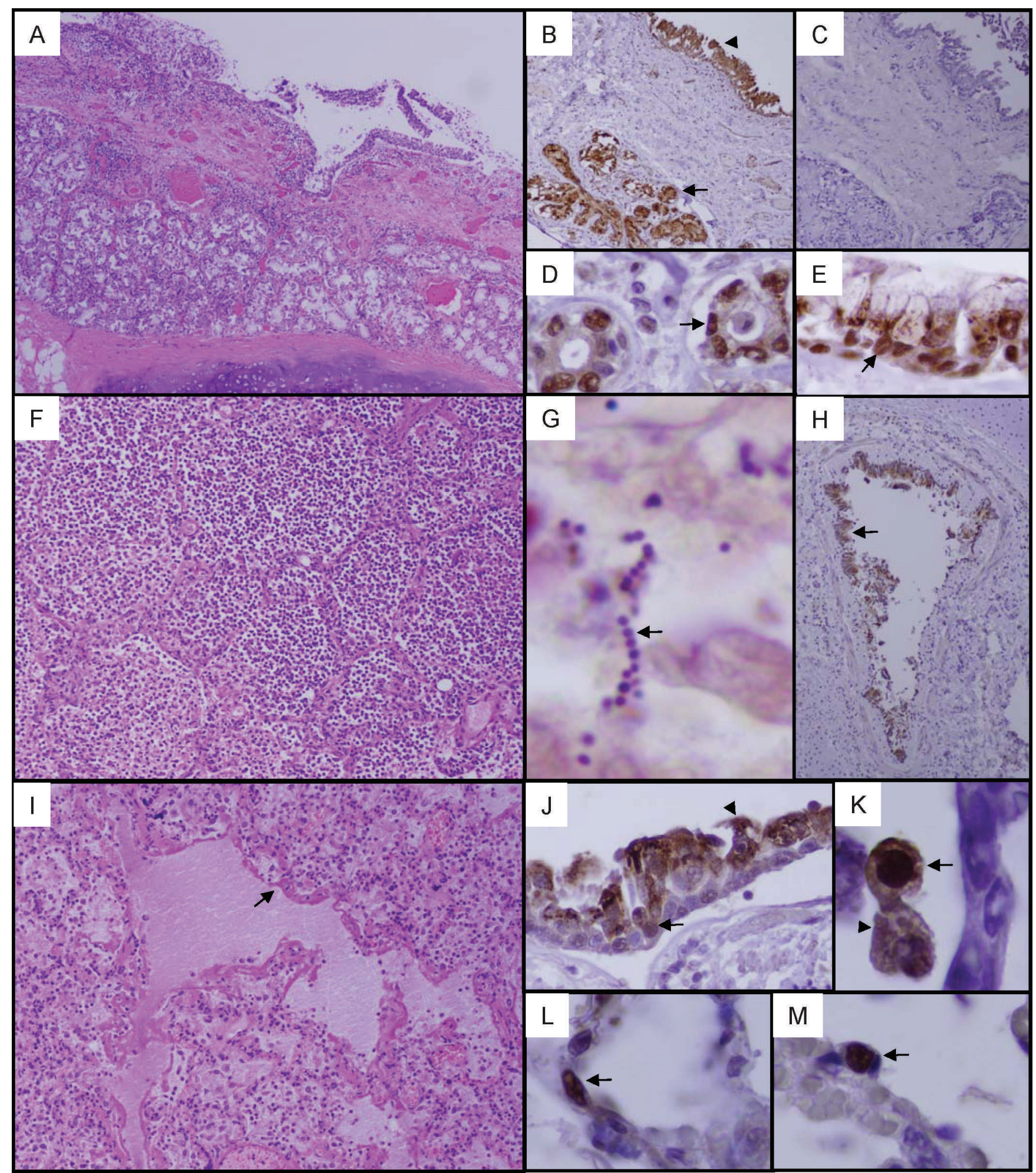

Figure 1. Representative histopathologic changes associated with fatal pandemic influenza A/H1N1 infection. Photomicrographs of hematoxylineosin-stained tissue sections and immunohistochemically stained sections to detect influenza viral antigen are shown. A, Acute necrotizing tracheitis and inflammation of the submucosal tracheal mucus glands (case 2) (hematoxylin-eosin, original magnification $\times 400$ ). B and $C$, Immunohistochemical stain for influenza in a section of trachea. Viral antigen is stained red-brown on a hematoxylin-stained background. Arrow shows influenza antigen-positive cells in the submucosal gland. Arrowhead shows influenza antigen-positive cells in the tracheal epithelium. Section stained with anti-influenza primary antibody in B and without the primary antibody in C demonstrating specific staining (case 15) (original magnifications $\times 100[B$ and $C])$. $D$ and $E$, Immunohistochemical staining for influenza in a section of trachea. Viral antigen is stained red-brown on a hematoxylin-stained background. Arrows show influenza antigen-positive cells in acinar cells of a submucosal gland (D) and in ductal mucus cells, including basal cells (E) (case 17) (original magnifications $\times 1000$ [D and E]). F, Section of lung showing a massive infiltration of neutrophils in the airspaces of alveoli associated with bacterial bronchopneumonia (case 19) (hematoxylin-eosin, original magnification $\times 100$ ). G, Brown and Hopps modified tissue Gram stain showing chains of bacteria (arrow) morphologically compatible with streptococci (case 19) (original magnification 


\section{MATERIALS AND METHODS}

\section{Patients}

In May 2009, the New York City Office of Chief Medical Examiner began investigating all suspected influenza deaths, including all unexplained deaths involving febrile respiratory illnesses and all sudden pediatric deaths with or without a history of febrile illness. Of the 42 confirmed New York City A/ H1N1 deaths investigated by the New York City Office of Chief Medical Examiner between May 15, 2009, and July 9, 2009, 32 underwent autopsy examination that included gross, microscopic, microbiologic, and toxicologic study. At family request, 10 additional cases were externally examined with nasopharyngeal swabs obtained for viral testing. In addition, 2 deaths from other jurisdictions (Washington State and Long Island, New York) were seen in consultation by one of us (W.D.T.).

\section{Pathologic and Microbiologic Studies}

Histologic examination included routine hematoxylin-eosin staining on formalin-fixed, paraffin-embedded (FFPE) respiratory tract sections. Sections from 33 of 34 fatal cases were examined for fungi using Gomori methenamine silver stain and for bacteria using Brown and Hopps tissue Gram stain.

Further microbiologic investigation included swabs of the nasopharynx and trachea in all autopsied cases with suspected or known A/H1N1 infection. Viral studies were performed by the Centers for Disease Control and Prevention and the New York City Public Health Laboratory. Novel A/H1N1 viral RNA was detected by real-time reverse transcription-polymerase chain reaction. ${ }^{14}$ Real-time reverse transcription-polymerase chain reaction was also performed on FFPE autopsy tissue sections ${ }^{15}$ for the influenza A virus matrix gene ${ }^{16,17}$ and novel A/H1N1 hemagglutinin gene..$^{18}$ Immunohistochemical studies for influenza A viral antigen were performed following antigen retrieval. ${ }^{19}$

\section{RESULTS \\ Study Patients}

Age and gender data (Tables 1 and 2) indicate that $62 \%$ of patients were 25 to 49 years old; fatal cases included 2 previously healthy infants (ages 2 and 4 months) and 1 person older than 60 years.

\section{Pulmonary Pathologic Findings}

A spectrum of histopathologic changes was observed in both the upper and lower respiratory tissues (Figure 1; Tables 2 and 3). Tracheitis and bronchitis of focal or extensive nature were observed in all cases (Figure 1, A through $\mathrm{E}$ and $\mathrm{H}$ ), typically consisting of denuded or ulcerated epithelial layers, focal squamous metaplasia, and submucosal inflammatory infiltrates. Moderate to marked inflammation of the submucosal glands and ducts with focal epithelial cytonecrosis was typical (Figure 1, A). Focal mild to moderate bronchiolitis (Figure 1, J) was observed in 18 of 34 cases, sometimes associated with squamous metaplasia.
Table 1. Characteristics of the 34 Study Decedents Who Had Confirmed Infection With Novel Influenza A/ H1N1 Virus and Underwent Autopsy

\begin{tabular}{|cc|}
\hline \multicolumn{1}{|c|}{ Characteristic } & Value \\
\hline Female sex, No./Total No. (\%) & $17 / 34(50)$ \\
Age, median (range), y & $41.5(0.16-72)$ \\
Age, y, No./Total No. (\%) & $2 / 34(6)$ \\
$\leq 5$ y & $0 / 34(0)$ \\
$>5$ to $\leq 10$ y & $1 / 34(3)$ \\
$>10$ to $\leq 15$ y & $21 / 34(62)$ \\
$>15$ to $\leq 50$ y & $9 / 34(26)$ \\
$>50$ to $\leq 60$ y & $1 / 34(3)$ \\
$>60$ y & \\
Symptom, No./Total No. (\%) & $30 / 32(94)$ \\
Fever (temperature $>38{ }^{\circ}$ C) & $31 / 34(91)$ \\
Cough & $24 / 33(73)$ \\
Dyspnea or respiratory distress & $12 / 21(57)$ \\
Mechanical ventilation on admission & $15 / 26(58)$ \\
Rhinorrhea & $12 / 24(50)$ \\
Myalgia/arthralgia & $8 / 17(47)$ \\
Clinical evidence of sepsis & $11 / 28(39)$ \\
Gastrointestinal symptoms & \\
Hypotension that did not resolve after & $6 / 18(33)$ \\
fluid administration & $3 / 21(14)$ \\
Wheezing & $2 / 28(7)$ \\
Hemoptysis & $37.5(21-70)$ \\
Body mass index, mean, median (range) & \\
Known in 27 deaths: time from onset of & \\
symptoms to death, median (range), d & \\
Known in 16 deaths: time from onset of & \\
symptoms to emergency room, median & \\
(range), d & \\
Known in 22 deaths: time from admission & \\
to death, median (range), ${ }^{\text {d d }}$ & \\
\hline
\end{tabular}

a Thirteen of 34 decedents were pronounced dead on arrival at the hospital or scene of death.

Influenza viral pneumonia with focal to extensive diffuse alveolar damage (DAD) was seen in 25 of 34 cases (Figure 1, I), often associated with marked hyaline membrane formation, pulmonary edema, and, in 8 of 34 cases, acute pulmonary hemorrhage. Sixteen of these 25 DAD cases showed only acute DAD (average time in hospital, 3.4 days). Seven of 25 cases showed acute and organizing DAD (average time in hospital, 11.7 days). Two of 25 cases had fibrosing and organizing DAD (average time in hospital, 31.5 days). Thrombotic changes similar to changes observed in $1918^{20}$ were seen in 9 of 34 cases. Autopsy evidence of acute pneumonias, ranging from focal to extensive in distribution, were observed in 19 of 34 cases (Figure 1, F), usually in association with bacteria (Figure 1, G; see Autopsy evidence of acute bacterial pneumonia and detection of bacteria).

$\leftarrow$

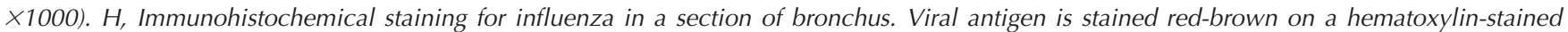

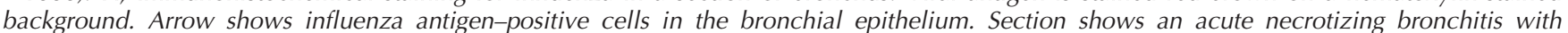

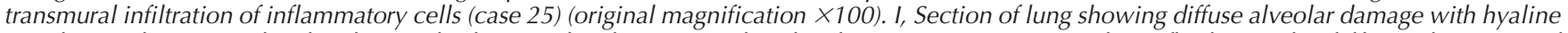

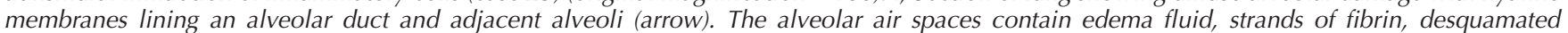

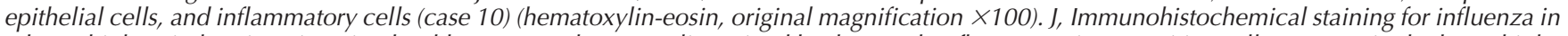

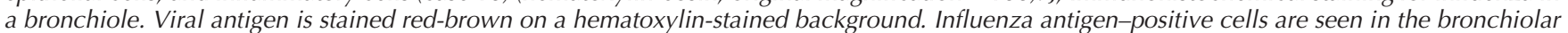
epithelium, including ciliated cells (arrowhead), and in the nuclei of some basilar cells (arrow) (case 25) (original magnification X400). K through $\mathrm{M}$,

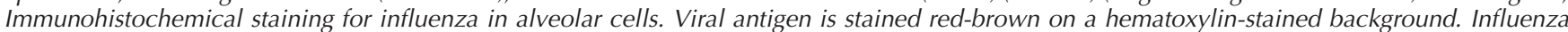
antigen-positive cells (arrows) include alveolar macrophages (K; case 1 ) and alveolar epithelial cells, both type I (L; case 15) and type II (M; case 24).

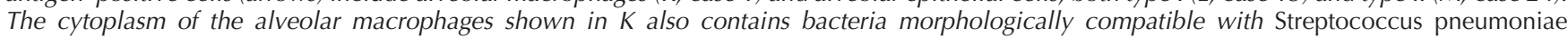
(arrowhead) (original magnifications $\times 1000$ [K, L, and M]). 
Table 2. Pulmonary Pathology Microscopic and Microbiologic Findings of the 34 Study Decedents Who Had Confirmed Infection With Novel Influenza A/H1N1 Virus and Underwent Autopsy

\begin{tabular}{|c|c|c|c|c|c|c|c|c|}
\hline $\begin{array}{l}\text { Case } \\
\text { No. }\end{array}$ & Age/Sex & $\begin{array}{l}\text { Underlying } \\
\text { Medical } \\
\text { Conditions }\end{array}$ & $\begin{array}{c}\text { Length of } \\
\text { Hospitalization }\end{array}$ & $\begin{array}{l}\text { Major Histopathologic } \\
\text { Findings }\end{array}$ & $\begin{array}{l}\text { Bacteriologic } \\
\text { Results }^{\mathrm{a}}\end{array}$ & $\begin{array}{l}\text { Gram } \\
\text { Stain }^{\text {b }}\end{array}$ & $\begin{array}{l}\text { Influenza } \\
\text { IHC }^{c}\end{array}$ & $\begin{array}{l}\text { Influenza } \\
\text { PCR }^{\mathbf{d}}\end{array}$ \\
\hline 1 & $55 \mathrm{y} / \mathrm{F}$ & $\begin{array}{l}\text { Down syndrome, } \\
\text { cirrhosis }\end{array}$ & $36 \mathrm{~h}$ & $\begin{array}{l}\text { Acute bacterial pneumonia, } \\
\text { focal acute DAD, } \\
\text { tracheitis, bronchitis }\end{array}$ & $\begin{array}{l}\text { Streptococcus } \\
\text { pneumoniae }\end{array}$ & +++ & + & + \\
\hline 2 & $41 \mathrm{y} / \mathrm{F}$ & $\begin{array}{r}\text { Asthma, HTN, } \\
\text { DM, obesity }\end{array}$ & DOA & Asthmatic bronchitis & - & - & $+($ trachea $)$ & $+($ trachea $)$ \\
\hline 3 & $2 \mathrm{mo} / \mathrm{M}$ & None & DOA & $\begin{array}{l}\text { Cellular interstitial } \\
\text { pneumonia, focal acute } \\
\text { bacterial pneumonia, } \\
\text { focal acute bronchiolitis }\end{array}$ & $S$ pneumoniae & + & + & + \\
\hline 4 & $43 \mathrm{y} / \mathrm{F}$ & $\begin{array}{l}\text { Asthma, COPD, } \\
\text { IVDA }\end{array}$ & $16 \mathrm{~h}$ & $\begin{array}{l}\text { Extensive necrotizing } \\
\text { bacterial pneumonia, } \\
\text { focal acute DAD }\end{array}$ & MRSA & +++ & + & + \\
\hline 5 & $72 \mathrm{y} / \mathrm{F}$ & $\begin{array}{l}\text { AIDS (most } \\
\text { recent CD4, } \\
\text { 290/mm³), } \\
\text { HTN, CAD, } \\
\text { substance } \\
\text { abuse, home } \\
\text { oxygen } \\
\text { therapy }\end{array}$ & $24 \mathrm{~h}$ & $\begin{array}{l}\text { Acute and chronic } \\
\text { bronchiolitis }\end{array}$ & - & - & + & + \\
\hline 6 & $53 \mathrm{y} / \mathrm{M}$ & $\begin{array}{l}\text { CHF with AICD, } \\
\text { HTN, DM }\end{array}$ & $17 \mathrm{~h}$ & $\begin{array}{l}\text { Tracheitis and asthmatic } \\
\text { bronchitis, changes } \\
\text { consistent with CHF }\end{array}$ & - & - & + & + \\
\hline 7 & $30 \mathrm{y} / \mathrm{M}$ & $\begin{array}{l}\text { HTN, obesity, } \\
\text { DM }\end{array}$ & $40 d$ & $\begin{array}{l}\text { Focal acute bacterial } \\
\text { pneumonia, pulmonary } \\
\text { edema }\end{array}$ & $S$ pneumoniae & + & - & - \\
\hline 8 & $34 \mathrm{y} / \mathrm{M}$ & Asthma, obesity & DOA & $\begin{array}{l}\text { Focal acute and organizing } \\
\text { bacterial pneumonia, } \\
\text { focal DAD, asthmatic } \\
\text { bronchitis }\end{array}$ & S pneumoniae & + & + & + \\
\hline 9 & $47 \mathrm{y} / \mathrm{F}$ & Obesity & DOA & $\begin{array}{l}\text { Marked acute DAD with } \\
\text { marked hyaline } \\
\text { membranes, focal acute } \\
\text { pneumonia }\end{array}$ & - & +++ & + & + \\
\hline 12 & $46 \mathrm{y} / \mathrm{M}$ & Obesity, HTN & DOA & $\begin{array}{l}\text { Acute DAD with focal } \\
\text { hyaline membranes, } \\
\text { extensive pulmonary } \\
\text { edema, acute pneumonia, } \\
\text { focal mild chronic } \\
\text { bronchiolitis }\end{array}$ & - & - & + & + \\
\hline 13 & $31 \mathrm{y} / \mathrm{M}$ & Obesity & $7 d$ & $\begin{array}{l}\text { Acute DAD, acute } \\
\text { necrotizing pneumonia }\end{array}$ & - & - & + & - \\
\hline 14 & $47 \mathrm{y} / \mathrm{F}$ & $\begin{array}{l}\text { HTN, CAD, } \\
\text { IVDA }\end{array}$ & $9 \mathrm{~h}$ & $\begin{array}{l}\text { Acute DAD with focal } \\
\text { hyaline membranes, } \\
\text { extensive pulmonary } \\
\text { edema, focal acute } \\
\text { bacterial pneumonia }\end{array}$ & $\begin{array}{l}S \text { pyogenes } \\
\text { (GAS) }\end{array}$ & +++ & + & - \\
\hline 15 & $54 \mathrm{y} / \mathrm{F}$ & $\begin{array}{l}\text { Multiple } \\
\text { myeloma, } \\
\text { status post } \\
\text { stem cell } \\
\text { transplant, } \\
\text { obesity, HTN }\end{array}$ & $16 d$ & $\begin{array}{l}\text { Acute DAD with marked } \\
\text { hyaline membranes, } \\
\text { acute infarct and } \\
\text { thromboemboli }\end{array}$ & - & - & + & + \\
\hline 16 & $58 \mathrm{y} / \mathrm{F}$ & $\begin{array}{l}\text { HTN, } \\
\text { emphysema, } \\
\text { psoriasis on } \\
\text { infliximab } \\
\text { (Remicade) }\end{array}$ & DOA & $\begin{array}{l}\text { Acute DAD with marked } \\
\text { hyaline membranes, } \\
\text { ulcerative laryngitis }\end{array}$ & NT & ++ & + & + \\
\hline 17 & $32 \mathrm{y} / \mathrm{M}$ & $\begin{array}{l}\text { ESRD, DM, } \\
\text { HTN, CAD }\end{array}$ & DOA & $\begin{array}{l}\text { Mild bronchitis and } \\
\text { bronchiolitis }\end{array}$ & - & NT & + (trachea) & - \\
\hline
\end{tabular}




\section{Continued}

\begin{tabular}{|c|c|c|c|c|c|c|c|c|}
\hline $\begin{array}{l}\text { Case } \\
\text { No. }\end{array}$ & Age/Sex & $\begin{array}{l}\text { Underlying } \\
\text { Medical } \\
\text { Conditions }\end{array}$ & $\begin{array}{c}\text { Length of } \\
\text { Hospitalization }\end{array}$ & $\begin{array}{l}\text { Major Histopathologic } \\
\text { Findings }\end{array}$ & $\begin{array}{c}\text { Bacteriologic } \\
\text { Results }^{\mathrm{a}}\end{array}$ & $\begin{array}{l}\text { Gram } \\
\text { Stain }^{\text {b }}\end{array}$ & $\begin{array}{l}\text { Influenza } \\
\text { IHC }^{c}\end{array}$ & $\begin{array}{c}\text { Influenza } \\
\text { PCR }^{\mathbf{d}}\end{array}$ \\
\hline 18 & $49 \mathrm{y} / \mathrm{F}$ & $\begin{array}{l}\text { HTN, HIV, } \\
\text { asthma, } \\
\text { COPD, DM }\end{array}$ & $6 d$ & $\begin{array}{l}\text { Acute DAD with marked } \\
\text { hyaline membranes, focal } \\
\text { acute bacterial } \\
\text { pneumonia }\end{array}$ & - & + & + & + \\
\hline 19 & $56 \mathrm{y} / \mathrm{F}$ & HTN, obesity & DOA & $\begin{array}{l}\text { Acute necrotizing bacterial } \\
\text { pneumonia, pulmonary } \\
\text { edema, bronchitis and } \\
\text { bronchiolitis }\end{array}$ & $\begin{array}{l}S \text { pyogenes } \\
\text { (GAS) }\end{array}$ & ++ & + & + \\
\hline 20 & $25 \mathrm{y} / \mathrm{F}$ & $\begin{array}{l}39 \text { weeks } \\
\text { pregnancy, } \\
\text { HTN, } \\
\text { preeclampsia }\end{array}$ & $18 d$ & $\begin{array}{l}\text { Acute and organizing DAD, } \\
\text { acute necrotizing } \\
\text { bacterial pneumonia }\end{array}$ & - & + & + & - \\
\hline 21 & $31 \mathrm{y} / \mathrm{M}$ & $\begin{array}{l}\text { Slightly obese } \\
\text { (autopsy BMI, } \\
\text { 35) }\end{array}$ & $9 d$ & $\begin{array}{l}\text { Acute and organizing DAD, } \\
\text { acute infarct and } \\
\text { thromboemboli, focal } \\
\text { acute pneumonia }\end{array}$ & - & - & + & + \\
\hline 23 & $55 \mathrm{y} / \mathrm{F}$ & Asthma, IVDA & $13 d$ & $\begin{array}{l}\text { Acute and organizing DAD } \\
\text { with marked hyaline } \\
\text { membranes, asthmatic } \\
\text { tracheitis and bronchitis }\end{array}$ & - & + & + & - \\
\hline 24 & $55 \mathrm{y} / \mathrm{M}$ & $\begin{array}{l}\text { HTN, CAD, } \\
\text { obesity }\end{array}$ & $4 d$ & Focal acute DAD & - & - & + & - \\
\hline 25 & $4 \mathrm{mo} / \mathrm{M}$ & None & DOA & $\begin{array}{l}\text { Chronic bronchitis and } \\
\text { bronchiolitis }\end{array}$ & - & - & + & + \\
\hline 26 & $59 \mathrm{y} / \mathrm{F}$ & HTN, CAD & $10 \mathrm{~d}$ & Acute and organizing DAD & - & - & + & + \\
\hline 27 & $28 \mathrm{y} / \mathrm{M}$ & Obesity, asthma & DOA & Acute bacterial pneumonia & $S$ pneumoniae & +++ & + & + \\
\hline 28 & $44 \mathrm{y} / \mathrm{F}$ & $\mathrm{HTN}$ & DOA & Acute and organizing DAD & $S$ pneumoniae & ++ & + & - \\
\hline 33 & 39 y/M & $\begin{array}{l}\text { Obesity, } \\
\text { hypertrophic } \\
\text { cardio- } \\
\text { myopathy }\end{array}$ & DOA & $\begin{array}{l}\text { Acute DAD, changes } \\
\text { consistent with CHF }\end{array}$ & NT & - & + & + \\
\hline 34 & $42 \mathrm{y} / \mathrm{F}$ & Overweight & $38 \mathrm{~d}$ & $\begin{array}{l}\text { Fibrosing and organizing } \\
\text { DAD, focal acute and } \\
\text { chronic pneumonia }\end{array}$ & NT & - & + & + \\
\hline
\end{tabular}

Abbreviations: - , negative; AICD, automatic implantable cardioverter defibrillator; AML, acute myelogenous leukemia; BMI, body mass index $\mathrm{CAD}$, coronary artery disease; CHF, congestive heart failure; COPD, chronic obstructive pulmonary disease; DAD, diffuse alveolar damage; DM, diabetes mellitus; DOA, dead on arrival; ESRD, end-stage renal disease; GAS, Group A streptococci; HIV, human immunodeficiency virus; HTN, hypertension; IHC, immunohistochemistry; IVDA, intravenous drug abuse; MDS, myelodysplastic syndrome; MRSA, methicillin-resistant Staphylococcus aureus; NT, not tested; PCR, polymerase chain reaction.

${ }^{a}$ Postmortem bacteriologic results listed include culture, immunohistochemistry, and/or PCR. Lung tissue from 30 of 34 fatal cases was examined by immunohistochemistry for specific bacterial antigens (Streptococcus pneumoniae, Streptococcus pyogenes, Staphylococcus aureus, and Haemophilus influenzae ${ }^{21,22}$ at the Centers for Disease Control and Prevention's Infectious Diseases Pathology Branch.

b Tissue Gram stain results listed as +++, numerous Gram-positive bacteria present; ++, Gram-positive bacteria present; +, rare Gram-positive bacteria present; NT, not tested.

${ }^{\mathrm{C}}$ Influenza immunohistochemistry was performed using a polyclonal anti-nucleoprotein antibody as previously described ${ }^{19}$ and was scored as either positive $(+)$ or negative $(-)$; (trachea), positive only in trachea not in lung sections.

d Reverse transcriptase-polymerase chain reaction for influenza viral RNA was performed from RNA extracted from the formalin-fixed paraffinembedded autopsy tissue blocks using primer sets for the influenza A virus matrix gene and specific primer sets for the pandemic $\mathrm{H} 1 \mathrm{~N} 1$ virus, scored as positive (+) or negative $(-)$; (trachea), positive only in trachea not in lung sections. 


\section{Influenza Viral Detection}

Novel A/H1N1 virus was detected antemortem or at autopsy in all 34 decedents, including by real-time reverse transcription-polymerase chain reaction on postmortem nasopharyngeal and/or tracheal swab samples in $28(82 \%)$ and by real-time reverse-transcription polymerase chain reaction on FFPE lung and/or tracheal tissues in 23 of 34 cases (68\%; Table 2). The longest interval in which viral RNA was detected after the onset of respiratory symptoms was 12 days for postmortem nasopharyngeal samples and 38 days for FFPE material. The 6 decedents in which viral RNA was not detected in nasopharyngeal samples had intervals between 17 and 44 days; all had received oseltamivir phosphate (Tamiflu) while hospitalized, and 5 of the 6 had antemortem detection of H1N1 viral RNA. H1N1 RNA was subsequently detected by real-time reverse transcription-polymerase chain reaction from FFPE lung in the sixth decedent. Twelve of 18 inpatients were treated with oseltamivir phosphate and 4 other outpatients received prescriptions. Two outpatient prescriptions were not filled.

Immunohistochemistry for influenza viral antigen revealed prominent staining in the pseudostratified columnar epithelium of the tracheobronchial tree (Figure $1, \mathrm{~B}$ and $\mathrm{H}$ ) and its associated submucosal glands (Figure 1, D and E). Focal viral antigen positivity in bronchiolar epithelium was seen (Figure 1, J). Viral antigen was seen commonly in alveolar macrophages but was seen less frequently in alveolar type I and type II cells (Figure 1, K through M). Viral antigen was often detected both in the cytoplasm and in the nuclei of alveolar macrophages, suggesting viral replication in macrophages. Antigen-positive alveolar macrophages containing visible cytoplasmic bacteria were also observed (Figure 1, K).

\section{Autopsy Evidence of Acute Bacterial Pneumonia and Detection of Bacteria}

Autopsy evidence of acute pneumonia was seen in 19 of 34 cases $(56 \%)$ and was necrotizing/extensive in 5 cases $(15 \%)$. Thirty-three of 34 cases were examined for evidence of pulmonary bacterial infection by tissue Gram stain. Of these, 18 (55\%) showed bacterial pneumonia, 16 being morphologically compatible with streptococci and 2 with staphylococci. Of the 30 cases evaluated by postmortem bacteriologic culture and immunohistochemistry, 10 (4 of whom had been hospitalized before death) had evidence of bacterial infection: 6 with Streptococcus pneumoniae, 2 with Streptococcus pyogenes, 1 with $S$ pneumoniae and $S$ pyogenes, and 1 with methicillin-resistant Staphylococcus aureus (Tables 2 and 3). ${ }^{21,22}$ Most of these bacterial-positive cases (15 of 18; 83\%) also had histologic evidence of acute pneumonia, consistent with the high percentage of secondary bacterial pneumonia described in fatal cases from earlier pandemics. ${ }^{23-25}$ The remaining 3 had acute and organizing DAD with chronic inflammatory cells and bronchiolitis.

\section{Radiographic Findings}

Chest radiographs demonstrated features ranging from patchy opacities to areas of confluent density (not shown), corresponding with radiologic pulmonary features characterized in greater detail on computed tomography (CT) (Figure 2, A through D). On CT, the lungs of all 4 patients displayed patchy ground-glass opacities, in which underlying parenchymal architecture remained visible with discernible bronchovascular margins in a predominantly peripheral and peribronchial distribution, consistent with DAD. One case (Figure 2, D) also showed areas of denser consolidation obscuring underlying parenchymal architecture and bronchovascular margins, consistent with a secondary bacterial pneumonia identified at autopsy.

\section{Risk Factors and Comorbidities}

Of the 20 New York City deaths following hospital admission, 6 occurred in municipal hospitals and 14 in private hospitals. Twelve of these 20 patients presented in advanced respiratory distress requiring mechanical ventilation on admission. Ten (29\%) had outpatient visits prior to death or subsequent hospitalization. Gastrointestinal symptoms, including nausea, vomiting, diarrhea, and/or abdominal pain, were described in the medical records of 11 of 28 decedents.

Causes of death, risk factors for death, and comorbidities are summarized in Table 4 . Obesity, heart disease, and underlying pulmonary disease were most common. One A/H1N1-positive patient's death (case 6) was certified as a complication of hypertensive and atherosclerotic cardiovascular disease and of diabetes mellitus. Despite histologic evidence of tracheitis and bronchiolitis, A/H1N1 infection was not included as a cause of death in this patient. The 1 patient in the series older than 60 years (case 5) also had AIDS.

Seventy-two percent of the adult and adolescent decedents were obese (body mass index $[\mathrm{BMI}] \geq 30)^{26}$ (Table 4). The single adolescent death in the series had a BMI of 34. Among the 11 adults who were dead on arrival (and therefore received no fluid resuscitation), the median BMI was 47 (range, 25-62). A pregnant woman, who presented at 39 weeks' gestation with fever, cough, obesity, and preeclampsia, died of $\mathrm{A} / \mathrm{H} 1 \mathrm{~N} 1$ respiratory complications following an emergent Cesarean section.

Two adult decedents without significant underlying illnesses were slightly obese. One (case 21) had a BMI of 35 following 9 days of hospitalization with significant fluid overload at autopsy. The second (case 34) had a BMI of 38 at autopsy but had been admitted to hospital 38 days earlier with a BMI of 27 and subsequently developed marked anasarca. One decedent (case 31) had no known comorbidities. Overall, 29 of 32 adult decedents (91\%) had underlying risk factors (Tables 2 and 4 ).

\section{COMMENT}

The decision by the New York City Office of Chief Medical Examiner to investigate deaths associated with infection by the 2009 pandemic influenza virus provides an opportunity to examine the pathogenesis of fatal pandemic influenza. Major findings include (1) tracheitis and/or bronchitis in all cases, with DAD-associated viral pneumonia as the primary pathology; (2) distribution of influenza viral antigen predominantly in the tracheobronchial epithelium and submucosal glands, and to a lesser extent in bronchiolar epithelium and alveolar epithelial cells and macrophages; (3) bacterial pneumonia in 55\%; and (4) comorbidities in $91 \%$ of adult and adolescent decedents (with obesity in $72 \%$ ). These pathologic findings are strikingly similar to those of published autopsy studies from the 1918 and 1957 pandemics and 


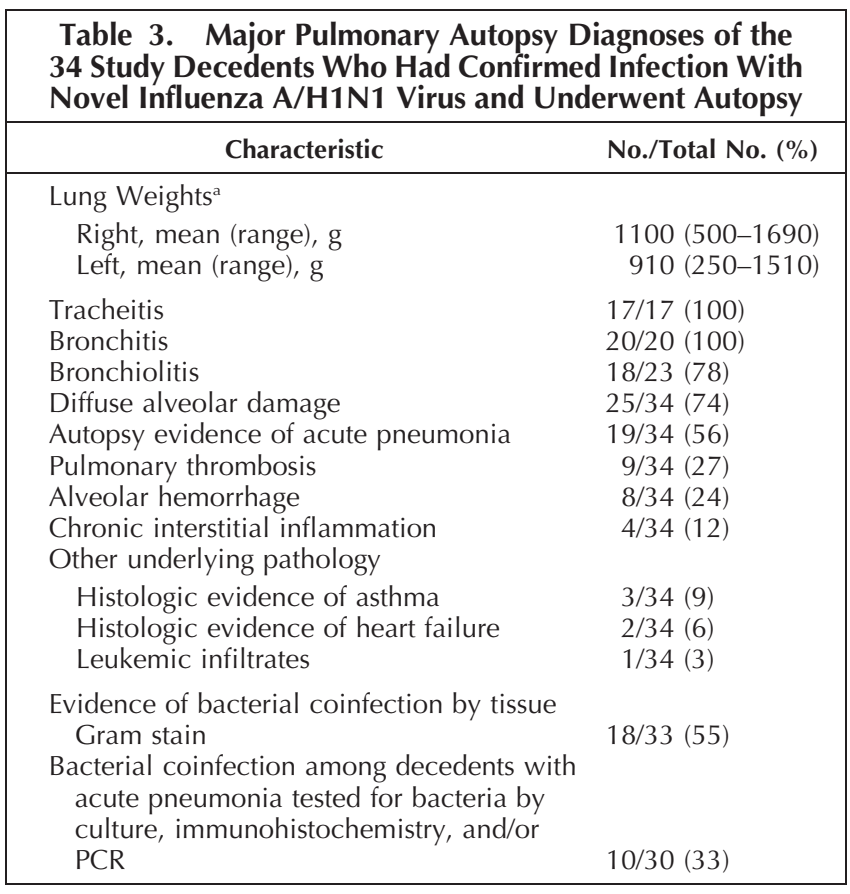

Abbreviation: PCR, polymerase chain reaction.

${ }^{a}$ Infant lung weights excluded (51 g, $43 \mathrm{~g}$ and 76 g, 55 g).

to a more limited extent from publications investigating seasonal influenza. ${ }^{23,25,27,28}$

Although pandemic and seasonal influenza generally cause self-limited illnesses, a small percentage of cases are fatal. ${ }^{25}$ In typical uncomplicated infections, viral replication apparently remains limited to the mucosal lining of the pharynx and upper tracheobronchial tree. Determinants of progression of a predominantly upper respiratory tract infection to fatal pulmonary disease are poorly understood but likely include a number of different factors such as age, immune and underlying health status, preexisting immunity to viral antigens (principally hemagglutinin), ${ }^{29}$ and pharyngeal bacterial flora. The findings in this and other studies ${ }^{24}$ suggest that severe disease is associated with the development of influenza viral pneumonia, ${ }^{23,25,30}$ with or without secondary bacterial pneumonia. ${ }^{24,31,32}$

The pulmonary pathologic abnormalities observed in the 2009 fatalities reported here do not differ significantly from those reported by pathologists who performed meticulous autopsies during the 1918 and 1957 pandemics (reviewed in references 23 and 25). For example, influenza viral antigen in the tracheobronchial epithelium, alveolar lining cells, and alveolar macrophages, as shown here by immunohistochemistry (Figure 1), was first demonstrated by immunofluorescence in 1957 pandemic autopsy cases..$^{23}$ Our observation that viral antigen in alveolar cells often did not colocalize with foci of DAD and alveolar hyaline membrane formation likely reflects the rapid asynchronous kinetics of influenza viral replication and clearance. ${ }^{25}$ It could also be consistent with recent speculation that at least some of the pulmonary abnormalities of fatal influenza viral pneumonia might be induced by the release of host inflammatory mediators, rather than by a direct viral cytopathic effect. ${ }^{33,34}$ Whether such pulmonary pathologic changes might also occur in patients with selflimited influenza infection is not known.
Table 4. Cause of Death and Contributing Conditions of the 34 Study Decedents Who Had Confirmed Infection With Novel Influenza A/H1N1 Virus and Underwent Autopsy

\begin{tabular}{cc}
\hline Characteristic & No./Total No. $(\%)$
\end{tabular}

Proximate cause of death

Novel influenza A (H1N1) viral respiratory infection

Novel influenza A (H1N1) viral respiratory $24 / 34(70)$ with immunocompromised state (ie, acute myelocytic leukemia, AIDS, myeloma with therapy, immunotherapy for psoriasis)

Novel influenza A (H1N1) viral respiratory infection complicating bronchial asthma

Diabetes mellitus with end-stage renal disease with novel influenza A ( $\mathrm{H} 1 \mathrm{~N} 1)$ viral respiratory infection as a contributing condition

Hypertensive cardiovascular disease with novel influenza A ( $\mathrm{H} 1 \mathrm{~N} 1)$

Viral respiratory infection as a contributing condition

Hypertensive and atherosclerotic cardiovascular disease

Comorbidities/contributing conditions/risk factors

Body mass index, mean, median (range) ${ }^{a} \quad 39.9,37.5$ (21-70)

Obesity $^{\mathrm{a}}$

Body mass index $\leq 30$

$23 / 32(72$

Body mass index $>30$ to $\leq 39$ (obesity)

$9 / 32(28)$

$8 / 32(25)$

Body mass index $>39$ (extreme obesity)

Obesity as sole risk factor ${ }^{\mathrm{a}}$

$15 / 32(47)$

$5 / 32(16)$

Heart disease (atherosclerotic, hypertensive, cardiomyopathy)

17/34 (50)

Chronic obstructive pulmonary disease/ asthma

Diabetes mellitus

$8 / 34(24)$

Infants

Pregnancy

End-stage kidney disease (diabetes mellitus)

$3 / 34(9)$

$2 / 34(6)$

$1 / 16(6)$

$1 / 34(3)$

Chronic substance abuse

$1 / 34(3)$

Cirrhosis (chronic hepatitis B)

$1 / 34(3)$

Immunocompromise

HIV positive (with AIDS)

Multiple myeloma with chemotherapy

and stem cell transplant

$3 / 34[2 / 34](9)$

Immunotherapy for psoriasis

Acute myelocytic leukemia

Total decedents with one or more comorbidity or risk factor ${ }^{a}$

Abbreviation: HIV, human immunodeficiency virus.

a The two infants were excluded.

Bacterial pneumonia was observed in $55 \%$ of the fatalities described here. In comparison, postmortem cultures for bacteria were positive in more than $90 \%$ of 1918 pandemic autopsies and about 75\% of 1957 autopsies. $^{23,25}$ Of the 13 decedents who died without having been hospitalized, $8(62 \%)$ had evidence of bacterial pneumonia (Table 2), suggesting that community acquired bacterial pneumonia may play a significant role in the current pandemic. In addition, 8 of these 13 decedents also had DAD, confirming that these changes are not just secondary to prolonged mechanical respirator support but a component of the viral disease process as described in the 1918 and 1957 pandemics. Nine decedents had pulmonary thrombi including 5 with focal infarcts. Thrombi are common with DAD and have been described with influenza infection since $1918{ }^{20,35}$ One of the 2 infant 

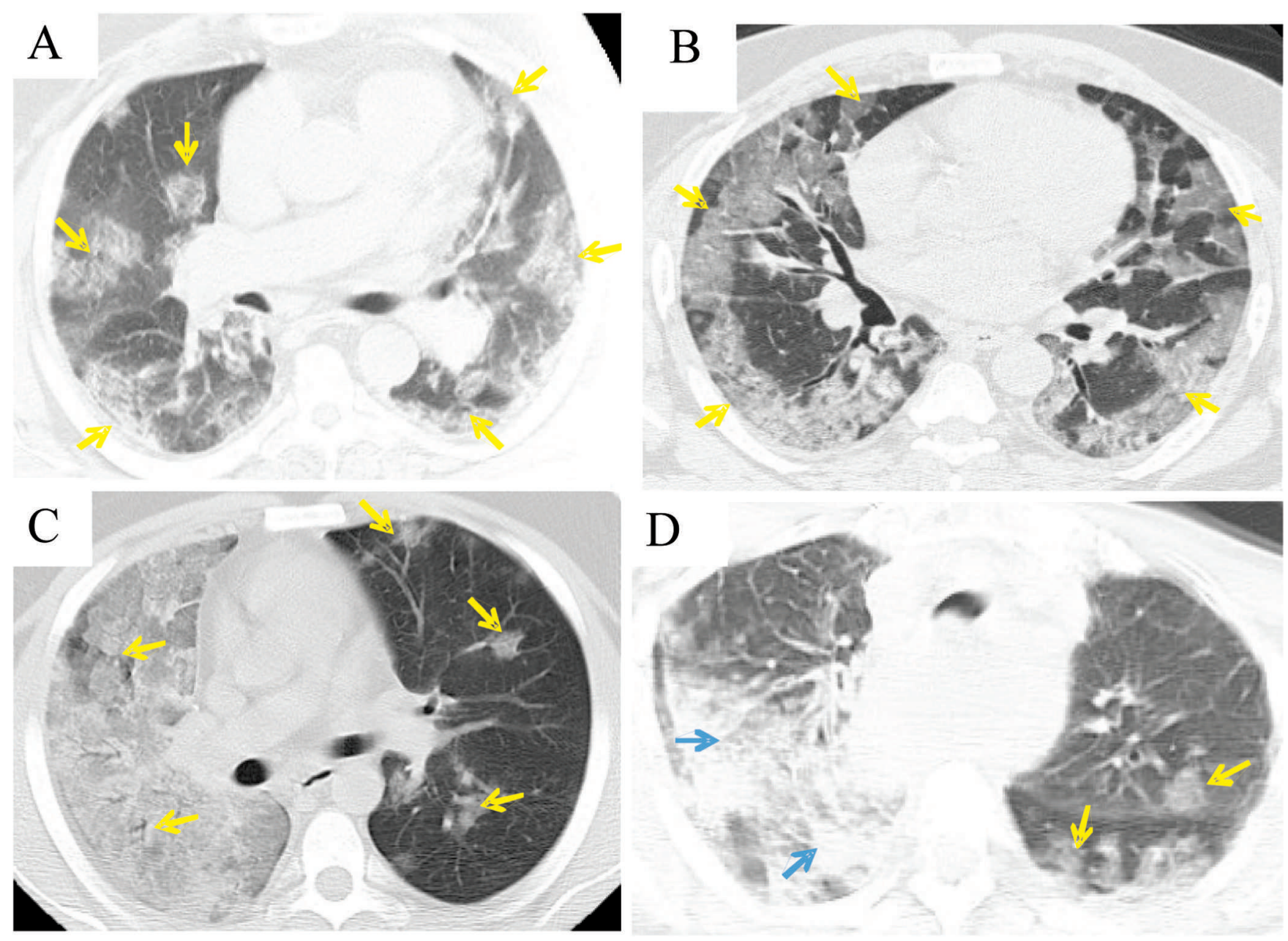

D

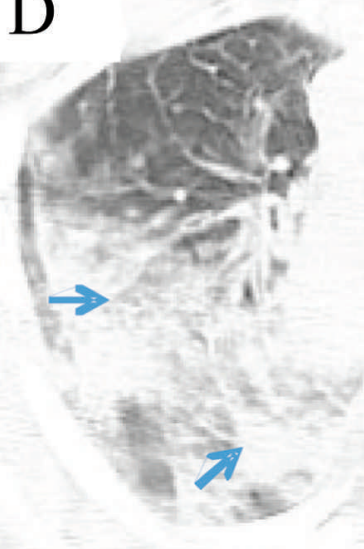

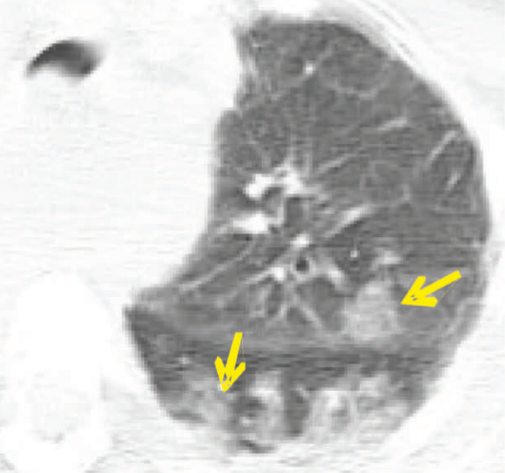

Figure 2. Chest computed tomography examinations. The lungs of all 4 patients show rounded patches of ground-glass peribronchial opacity (yellow arrows) in a peripheral distribution. In A (case 24), the opacities are discrete and multifocal, while in B (case 26) they are confluent in subpleural areas, and in C (case 21) the entire right lung displays confluent ground-glass attenuation. These changes may correspond to areas of diffuse alveolar damage seen on histopathologic examination (see text). In addition to patchy ground-glass opacities, D (case 1) shows areas of denser consolidation in the right upper lobe and the superior segment of the right lower lobe (blue arrows) that are consistent with the bacterial pneumonia diagnosed in this patient.

deaths (case 3) also had bacterial pneumonia. A recent report by the Centers for Disease Control and Prevention described concurrent bacterial infection in $29 \%$ of referral specimens from influenza A/H1N1 fatalities. ${ }^{21}$ As this report notes, inadequate sampling, collection of specimens from unaffected portions of the lung, or prolonged illness or treatment may limit the detection of bacteria and explain the variations in percentages of detection. ${ }^{21}$ Regardless, these findings suggest that, even in an era of widespread and early antibiotic use, bacterial pneumonia remains an important factor in severe/fatal influenza. In coming months it will be important for clinicians to diagnose and treat bacterial pneumonias occurring in patients infected with the pandemic influenza virus. Unfortunately, there is insufficient clinical information about the natural history of severe influenza disease to fully inform clinicians about optimal prophylaxis and treatment approaches.

In addition to demonstrating the characteristics and constancy of pulmonary abnormalities in fatal pandemic influenza, this case series emphasizes an association between underlying illnesses and mortality. Epidemiologic studies conducted during the current pandemic ${ }^{13,35}$ have suggested obesity as an important risk factor for fatal outcomes. Nearly half of the patients in this case series had a BMI greater than 40. Enhanced susceptibility to fatal infection in obese persons might reflect associated independent risk factors such as compromised ventilatory function, hypertension, congestive heart failure, or diabetes mellitus. ${ }^{36}$ The presence of only a single decedent older than 60 years is also consistent with current reports that older individuals are less vulnerable to infection with the 2009 A/H1N1 virus than with seasonal influenza viruses, presumably because of immunologic protection induced by prior exposure to previously circulating human A/ H1N1 viruses. ${ }^{37}$ It is not yet clear whether the comparatively few fatalities in older persons is due entirely to low incidence of infection by itself, or whether there may be lower case fatality as well. The frequent gastrointestinal symptomatology $(39 \%)$ in these patients is an area that needs further study with respect to the underlying pathology of the gastrointestinal tract.

A potentially important diagnostic modality in the new influenza pandemic is CT imaging, which provided detailed information on antemortem pathologic changes in the lungs of 4 patients in this case series. Our findings suggest that $\mathrm{CT}$ can be a valuable tool in identifying patients who will require intensive medical support and 
to elucidate the pathogenesis of severe disease. At present we do not know to what extent the CT abnormalities seen in these fatal cases also occur in patients with milder infections, but this question, as well as differentiating viral from bacterial infections, can be investigated in clinical trials, in volunteer challenge studies, and with quantitative CT analysis.

Pandemic progression offers an opportunity to study pandemic influenza viral infection using techniques not available in past pandemics, including enhanced surveillance, rapid genetic analyses, improved radiographic imaging techniques, and better tools to evaluate the immune response and the natural history of uncomplicated and severe disease. A better understanding of secondary bacterial pneumonias will be crucial for the treatment of severely ill influenza patients. Our findings suggest that, although the spectrum of pulmonary pathologic abnormalities has remained similar from pandemic to pandemic during the past 120 years, $^{24}$ the portion of the human population that is most susceptible to lethal infection differs with each new viral emergence, confirming the continuing importance of epidemiologic studies identifying risk groups and the continuing importance of careful autopsy pathology studies and the value of centralized evaluation of deaths by a medical examiner's office.

We thank Charles Hirsch, MD, chief medical examiner of the City of New York, for helpful discussions and a critical review of the manuscript.

\section{References}

1. Thompson WW, Shay DK, Weintraub E, et al. Mortality associated with influenza and respiratory syncytial virus in the United States. JAMA. 2003;289(2): 179-186.

2. Morens DM, Taubenberger JK, Fauci AS. The persistent legacy of the 1918 influenza virus. N Engl / Med. 2009:361(3):225-229.

3. Taubenberger JK, Morens DM. Pandemic influenza-including a risk assessment of H5N1. Rev Sci Tech. 2009;28(1):187-202.

4. Johnson NP, Mueller J. Updating the accounts: global mortality of the 19181920 "Spanish" influenza pandemic. Bull Hist Med. 2002;76(1):105-115.

5. Taubenberger JK, Morens DM. 1918 Influenza: the mother of all pandemics. Emerg Infect Dis. 2006;12(1):15-22.

6. Garten RJ, Davis CT, Russell CA, et al. Antigenic and genetic characteristics of swine-origin $2009 \mathrm{~A}(\mathrm{H} 1 \mathrm{~N} 1)$ influenza viruses circulating in humans. Science. 2009;325(5937):197-201.

7. Chan M. World now at the start of 2009 influenza pandemic. World Health Organization. http://www.who.int/mediacentre/news/statements/2009/ h1n1_pandemic phase6_20090611/en/index.html. Accessed June 15, 2009.

8. Pandemic (H1N1) 2009-update 64. World Health Organization. http:// www.who.int/csr/don/en/index.html. Accessed November 17, 2009.

9. Simonsen L, Clarke MJ, Schonberger LB, Arden NH, Cox NJ, Fukuda K. Pandemic versus epidemic influenza mortality: a pattern of changing age distribution. J Infect Dis. 1998;178(1):53-60.

10. Centers for Disease Control and Prevention. 2009 pandemic influenza A (H1N1) virus infections-Chicago, Illinois, April-July 2009. MMWR Morb Mortal Wkly Rep. 2009;58(33):913-918.

11. Kelly HA, Grant KA, Williams S, Fielding J, Smith D. Epidemiological characteristics of pandemic influenza H1N1 2009 and seasonal influenza infection. Med J Aust. 2009;191(3):146-149.

12. Baker MG, Wilson N, Huang QS, et al. Pandemic influenza $A(H 1 N 1) v$ in New Zealand: the experience from April to August 2009. Euro Surveill. 2009; 14(34):1-6.
13. Vaillant L, La Ruche G, Tarantola A, Barboza P. Epidemiology of fatal cases associated with pandemic H1N1 influenza 2009. Euro Surveill. 2009; 14(33): $1-6$.

14. Centers for Disease Control and Prevention. H1N1 flu (swine flu): resources for laboratories. Centers for Disease Control and Prevention Web site. http://www.cdc.gov/h1n1flu/lab/. Accessed June 2, 2009.

15. Krafft AE, Duncan BW, Bijwaard KE, Taubenberger JK, Lichy $J \mathrm{H}$ Optimization of the isolation and amplification of RNA from formalin-fixed, paraffin-embedded tissue: the Armed Forces Institute of Pathology experience and literature review. Mol Diagn. 1997;2(3):217-230.

16. Krafft AE, Russell KL, Hawksworth AW, et al. Evaluation of PCR testing of ethanol-fixed nasal swab specimens as an augmented surveillance strategy for influenza virus and adenovirus identification. J Clin Microbiol. 2005;43(4):17681775 .

17. Runstadler JA, Happ GM, Slemons RD, et al. Using RRT-PCR analysis and virus isolation to determine the prevalence of avian influenza virus infections in ducks at Minto Flats State Game Refuge, Alaska, during August 2005. Arch Virol. 2007;152(10):1901-1910.

18. Wang R, Sheng ZM, Taubenberger JK. Detection of novel (swine origin) H1N1 influenza A virus by quantitative real-time RT-PCR. J Clin Microbiol. 2009; 47(8):2675-2677.

19. Qi L, Kash JC, Dugan VG, et al. Role of sialic acid binding specificity of the 1918 influenza virus hemagglutinin protein in virulence and pathogenesis for mice. J Virol. 2009;83(8):3754-3761.

20. LeCount ER. Disseminated necrosis of the pulmonary capillaries in influenzal pneumonia. JAMA. 1919;72(21):1519-1520.

21. Centers for Disease Control and Prevention. Bacterial coinfections in lung tissue specimens from fatal cases of 2009 pandemic influenza A ( 11 N1) - United States, May-August 2009. MMWR Morb Mortal Wkly Rep. 2009;58:1-4.

22. Guarner J, Packard MM, Nolte KB, et al. Usefulness of immunohistochemical diagnosis of streptococcus pneumoniae in formalin-fixed, paraffinembedded specimens compared with culture and gram stain techniques. $\mathrm{Am}$ Clin Pathol. 2007;127(4):612-618.

23. Mulder J, Hers JFP. Influenza. Groningen, the Netherlands: WoltersNoordhoff Publishing; 1972:287.

24. Morens DM, Taubenberger JK, Fauci AS. Predominant role of bacterial pneumonia as a cause of death in pandemic influenza: implications for pandemic influenza preparedness. J Infect Dis. 2008;198(7):962-970.

25. Taubenberger JK, Morens DM. The pathology of influenza virus infections Annu Rev Pathol. 2008;3:499-522.

26. Yanovski SZ, Yanovski JA. Obesity. N Engl J Med. 2002;346(8):591-602.

27. Guarner J, Paddock CD, Shieh WJ, et al. Histopathologic and immunohistochemical features of fatal influenza virus infection in children during the 2003-2004 season. Clin Infect Dis. 2006;43(2):132-140.

28. Guarner J, Shieh WJ, Dawson J, et al. Immunohistochemical and in situ hybridization studies of influenza A virus infection in human lungs. Am J Clin Pathol. 2000;114(2):227-233.

29. Ahmed R, Oldstone MB, Palese P. Protective immunity and susceptibility to infectious diseases: lessons from the 1918 influenza pandemic. Nat Immunol. 2007;8(11):1188-1193.

30. Kuiken T, Taubenberger JK. The pathology of human influenza revisited. Vaccine. 2008;26(suppl 4):D59-D66.

31. McCullers JA. Planning for an influenza pandemic: thinking beyond the virus. J Infect Dis. 2008;198(7):945-947.

32. Klugman KP, Chien YW, Madhi SA. Pneumococcal pneumonia and influenza: a deadly combination. Vaccine. 2009;27(suppl 3):C9-C14.

33. Kash JC, Tumpey TM, Proll SC, et al. Genomic analysis of increased host immune and cell death responses induced by 1918 influenza virus. Nature. 2006; 443(7111):578-581.

34. de Jong MD, Simmons CP, Thanh TT, et al. Fatal outcome of human influenza $\mathrm{A}(\mathrm{H} 5 \mathrm{~N} 1)$ is associated with high viral load and hypercytokinemia. Nat Med. 2006;12(10):1203-1207.

35. Centers for Disease Control and Prevention. Intensive-care patients with severe novel influenza A (H1N1) virus infection-Michigan, June 2009. MMWR Morb Mortal Wkly Rep. 2009;58(27):749-752.

36. Haque AK, Gadre S, Taylor J, Haque SA, Freeman D, Duarte A. Pulmonary and cardiovascular complications of obesity: an autopsy study of 76 obese subjects. Arch Pathol Lab Med. 2008;132(9):1397-1404.

37. Centers for Disease Control and Prevention. Serum cross-reactive antibody response to a novel influenza $A(\mathrm{H} 1 \mathrm{~N} 1)$ virus after vaccination with seasona influenza vaccine. MMWR Morb Mortal Wkly Rep. 2009;58(19):521-524. 